\title{
TRADITION OF KOREAN LANDSCAPE. ITS HISTORIC PERSPECTIVE AND INDIGENIZATION
}

\author{
Hye Seung LEE \\ British International School of Wroclaw \\ Ojca Beyzyma 17 \\ 53-204 Wroclaw, Poland \\ hspol@hotmail.com
}

\begin{abstract}
This paper aims to provide general presentation of Korean landscape painting with historic consideration. Some Korean elements of landscape were introduced in the early 5th century, and since the 7th century, mountains have become an important theme in the formation of the image space. From the 10th to the 17 th centuries, the Korean landscape developed under Chinese rule. However, in the early $18^{\text {th }}$ century a new painting trend - "Koreanization of the Korean landscape" - appeared and there also had emerged the folk landscape style. Furthermore, in the contemporary Korean landscape there are various attempts towards the search for one's own artistic vision.
\end{abstract}

Key words: Korean Art, landscape painting, Korean painting

\section{한국 산수화의 전통. 그의 역사적 관점과 현지화/토착화}

개략: 본 논문은 한국 산수화에 대한 전반적인 역사적 고찰을 의도로 하고 있다. 5 세기 초 산수화에 한국적인 요소가 도입된 후 7 세기 이후 산을 주제로 한 장면은 이미지를 형성하는 주요 주제가 되어 왔다. 10-17 세기 한국의 산수화는 중국 양식을 통해 발전하였다. 하지만 18 세기 초 《한국 산수화의 한국화 »라는 새로운 경향이 일어났으며, 민속 산수화 양식도 나타났다. 뿐만 아니라 한국의 현대 산수화에는 특유의 새로운 예술 세계를 향해 다양한 시도가 나타나게 된다. 
키워드: 한국미술, 산수화, 한국화.

\title{
TRADYCJA KOREAŃSKIEGO MALARSTWA PEJZAŻOWEGO. PERSPEKTYWA HISTORYCZNA I NARODOWOŚCIOWA
}

\begin{abstract}
Abstrakt: Artykuł ma na celu przedstawienie koreańskiego malarstwa pejzażowego na tle historycznym. Niektóre element malarstwa pejzażowego pojawiły się w sztuce już w V wieku, a od VII wieku motyw gór stał się ważnym tematem. Od X do VII wieku widać wpływy chińskie na malarstwo koreańskie. Natomiast of XVIII wieku wyraźnie można zaobserwować nowy trend koreanistyczny oraz styl ludowy malarstwa pejzażowego. Natomiast we współczesnym malarstwie widoczne są tendencje do odnajdywania własnej wizji artystycznej w tym zakresie.
\end{abstract}

Słowa-klucze: sztuka koreańska, malarstwo pejzażowe, malarstwo koreańskie

\section{Beginning of the Korean landscape}

It's difficult to say, when the beginnings of the Korean landscape emerged. One can only suppose that some elements of landscape were introduced in the three kingdoms period. These include the ones that can be found in the wall painting preserved eg. in the tomb of the early 5th century, from the period of ancient Korean state of Koguryo. A simple mountain motif is shown there (picture No. 1; theme marked within yellow lines). It is the oldest known representation of this theme in Korean art. 


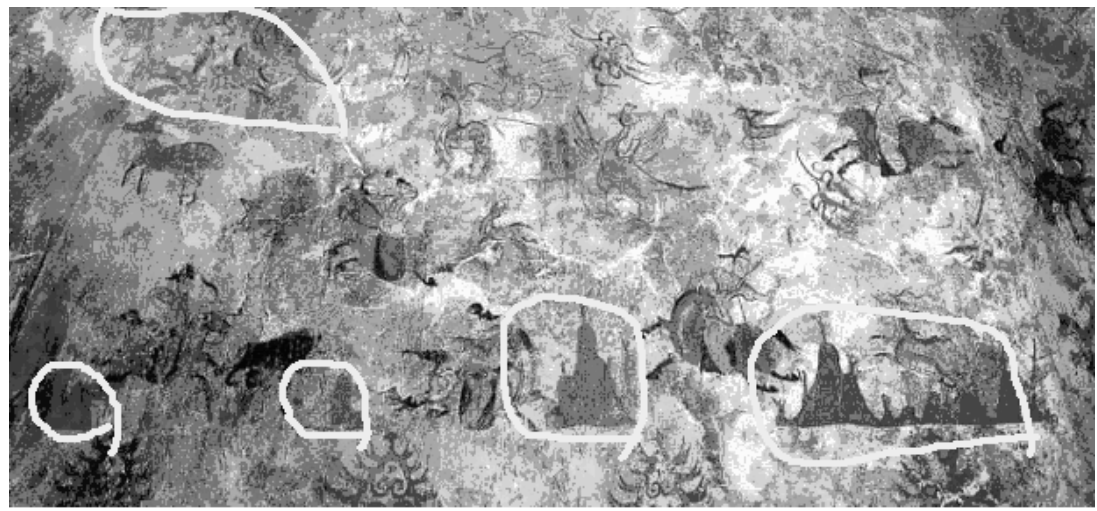

Image 1. "Hunting" (Suryeobdo 수렵도) in Dokhyngri tomb on a stone wall (409 B.C.)

Similarly, in image 2 coming from a slightly later period, mountains were exhibited; however, this element of the landscape determines the composition of the work to a lesser degree. In both of these wall paintings "mountains" are presented only as a side item, supplementing the dynamic nature of the composition which is an example of the contemporary painting style of ancient Korea.

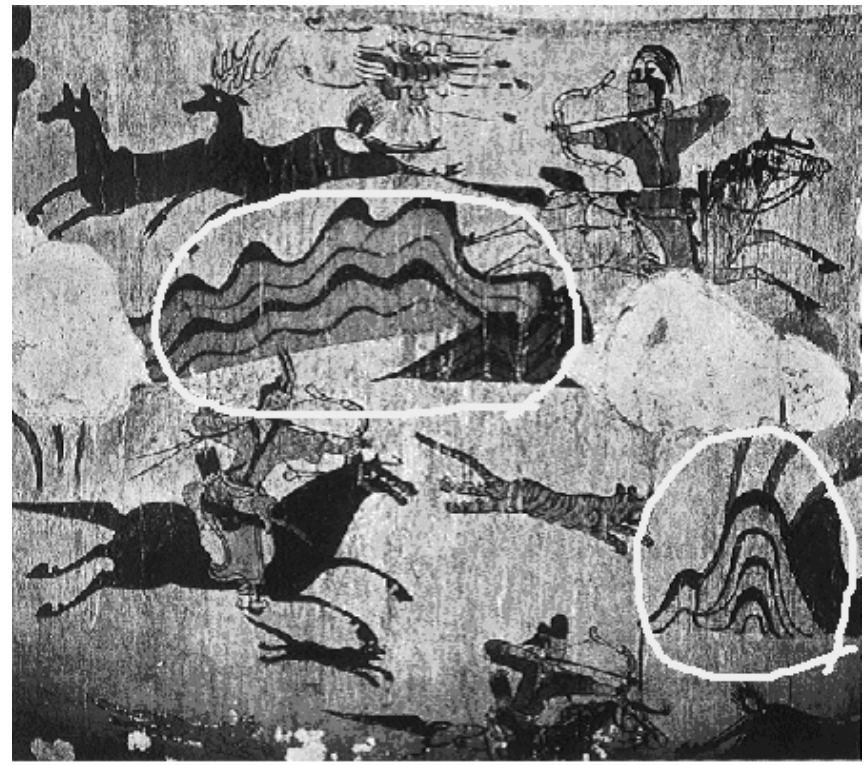


Image 2. "Hunting" (Suryeobdo 수렵도) in Muyongczong tomb on a stone wall (the turn of the $5^{\text {th }} / 6^{\text {th }}$ century)

However, since the 7th century, the mountain theme has been an important element in the formation of the image space. In figure 3, the layout of peaks layers and clouds over them already creates the illusion of perspective, becoming something more than just the background of the whole picture.

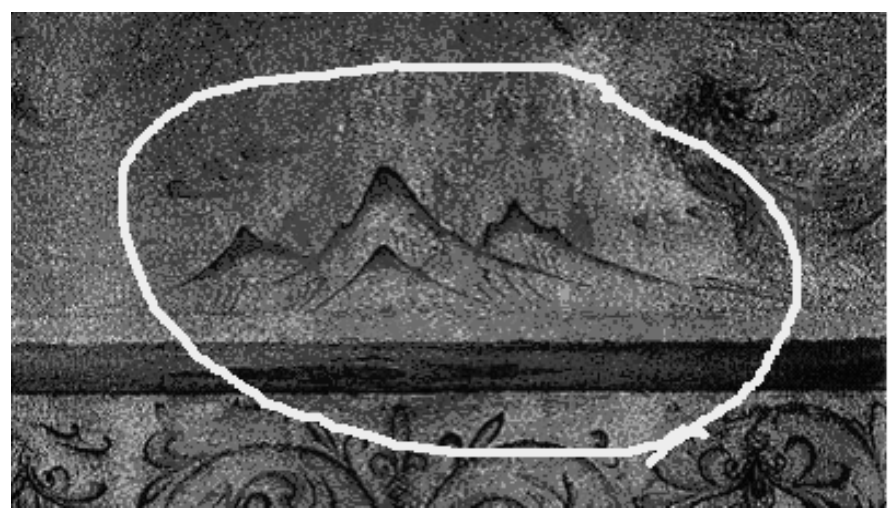

Image 3. "Mountains" (Sanakdo) in Gangsodaemyo tomb on a stone wall ( $7^{\text {th }}$ century)

It is considered that landscape has evolved in the southwestern State of Baekje in the same century. An example might be the impression in a brick (image 4), showing clear motives of landscapes, characterized by completely developed composition of space and perspective, with a clear differentiation among elements of surroundings (ie. the peaks of mountains, trees, rocks, clouds and the monastery visible at the foot). It is worth noting that this work was made in brick. Considering the painting of this period, the landscape was already at a very high level in the $7^{\text {th }}$ century. 


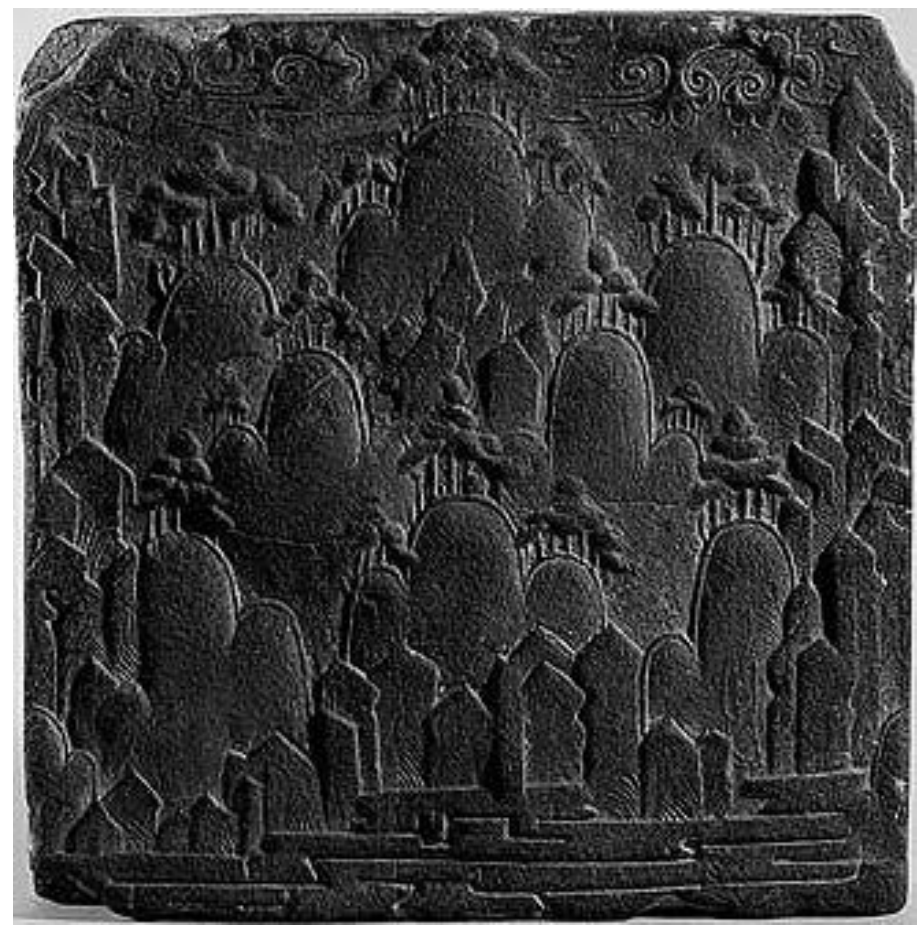

Image 4. Sansumunjeon. Brick with landscape project. Relief on brick. $\left(7^{\text {th }}\right.$ century)

Unfortunately, there is no information about landscape painting of the next unification period of Shilla (676-935). An important feature of this period is that the names of artists began to appear. For example, in historical bibliographic materials there is a record of an artist named Solgo (솔거), one of the most famous painters of the $8^{\text {th }}$ century. It was recorded that his landscape "Old Pine" (Noshongdo 老 松圖), which was painted on the wall of the Buddhist temple "Imperial Dragon" (Hwangryongsa 皇龍寺), was so realistic that birds could land on it. According to this record, is believed that in the $8^{\text {th }}$ century the type of "landscape of blue-green" (Cheongrok sansuhwa 靑綠山水 畫) was introduced, which is an important step in the realistic style of painting pines. This period includes the beginning of the Chinese painting school's influence in Korea. 


\section{The influence of Chinese schools (10-17 century)}

The period of the Goryeo Dynasty (高麗 918-1392) is the time in which the Korean landscape developed under Chinese rule. The characteristic feature of the teaching is based on "deliberate copying the works of masters" (Jeonimosa 轉移模寫). In the East Asian tradition of painting, such duplication was not regarded as a worthless action or appropriation of an artistic idea. Imitation of great artists was an expression of respect for the traditions and values of past generations and the recognition of the worth of their art. In this way, the student enters into the soul of a master - artist. He learns to recognise the form, colour, and technique from him.

During these periods, almost all educated Koreans followed mainly Chinese artists. For Asian artists, Guo Xi (郭熙 1020-1090) was an important figure. This Chinese artist had a big impact on the Korean painters and the way they created their works.

The main follower of Guo Xi style became An Kyon (安 堅 of the $15^{\text {th }}$ century.) - one of the greatest painters in the earlier period of the Korean Chosun Dynasty. He is known mainly through landscape under the title "Dream Visit to the Land of Peach" (Mongyudowondo 夢遊桃源圖 1447). This picture was painted at the request of the son of King Anpyong, who had told the painter, what he would like to see. During the dream Anpyong had seen a happy land that we call paradise. An artist An Kyon painted the dream of the king's son and thus created one of the most famous Korean paintings depicting both life on earth and that in paradise.

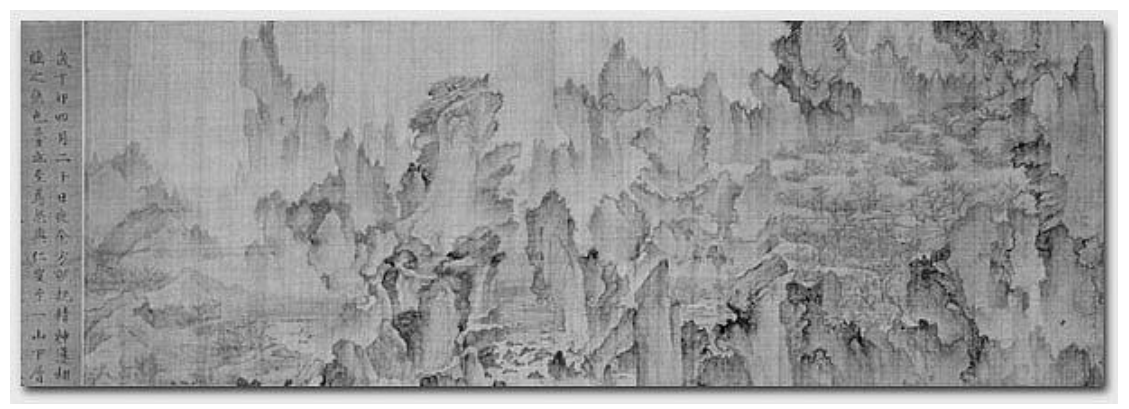


Image 5. An kyon, "Dream Visit to the Land of Peach" (1447) Watercolours and ink on silk

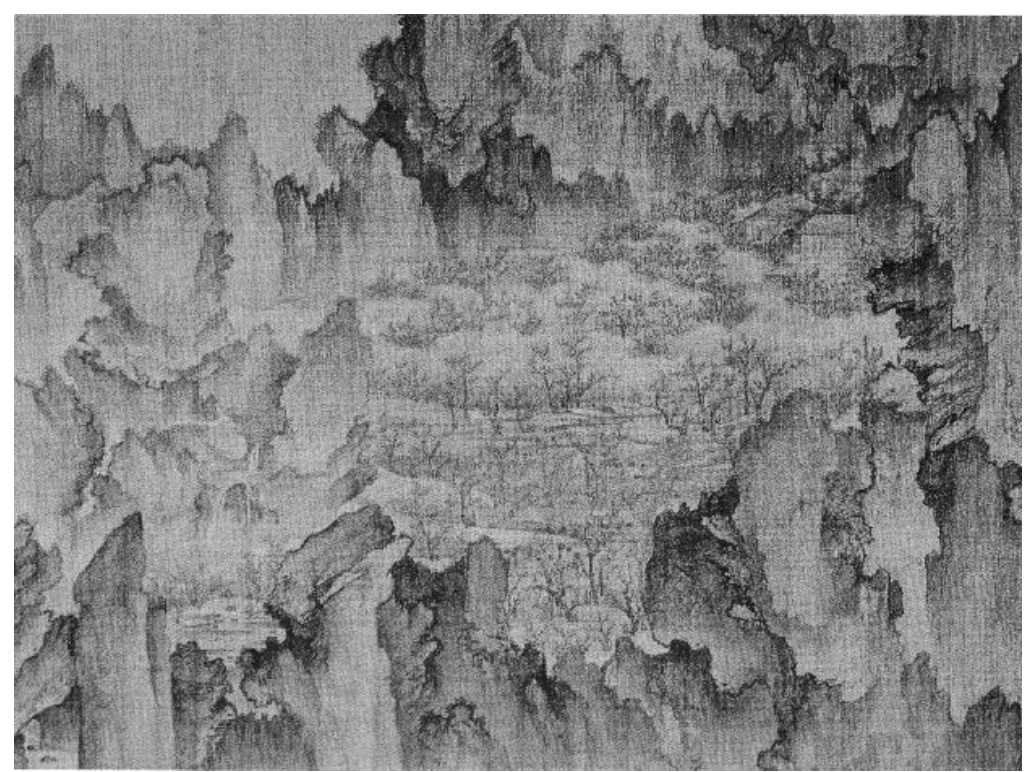

Image 5-1. Fragment of the "Dream Visit to the Land of Peach"

In the landscape we can see a variety of events that combine into a harmonious whole. Interestingly, in those days images which were painted on scrolls were viewed from right to left. However, the picture of An Kyon it is the opposite, which is extremely rare. It was his deliberate intention of the painting. Another interesting feature of this image are the inscriptions made by An Kyon containing his comments - philosophical thoughts. The painting on a long scroll is preserved to this day. On the basis of this work we can reproduce the painting style of the Chinese artist Guo Xi. 


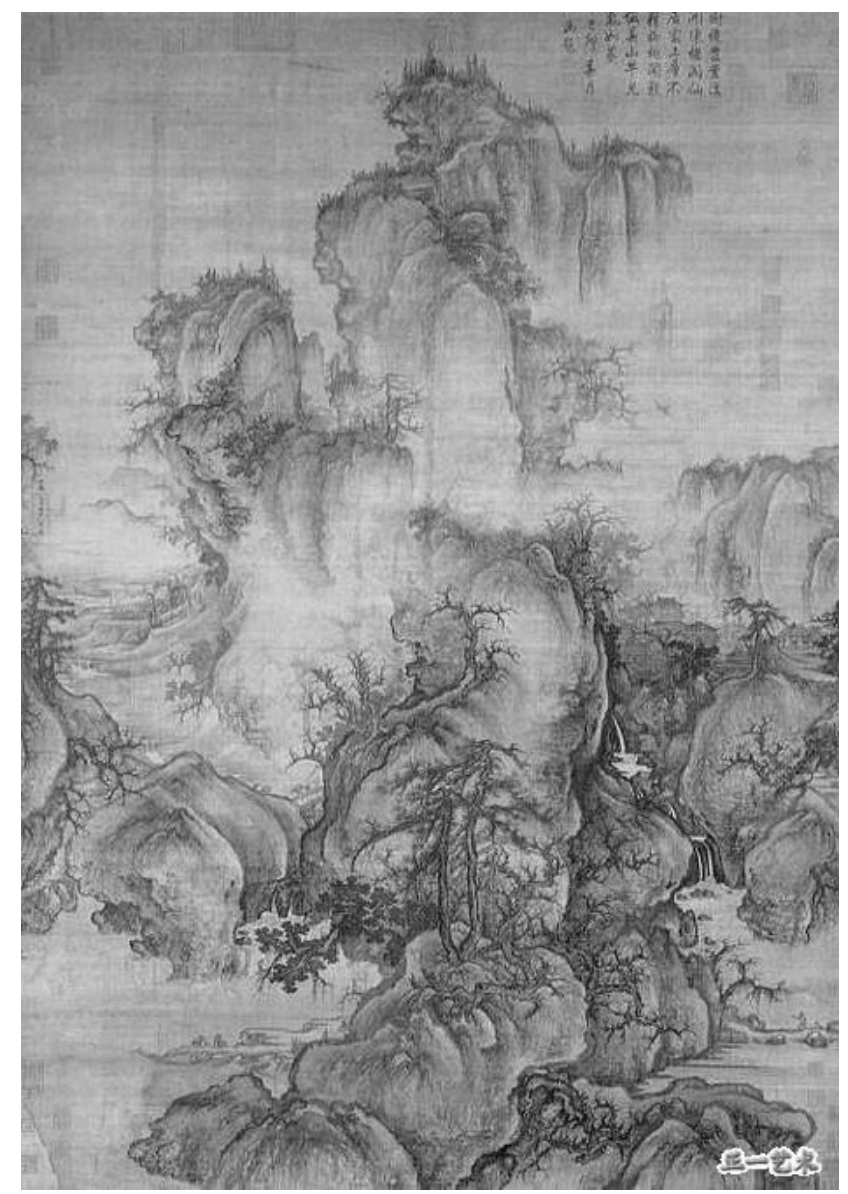

Image 6. Gou Xi, "Early spring" (1447 r.). Watercolours and ink on paper.

Guo Xi claimed that a good picture should give the recipient the impression that he may feel he can walk within it, could stay or live within it - which would be the best possibility. Landscape should be visually appealing and must produce an almost sensual feeling of the atmosphere of the place. This rule had a huge impact on the work of subsequent artists. Chinese and Korean painters tried to achieve this by accurate reproduction of even the smallest details of nature, e.g. pine-needles, clumps of grass, whirlpools or cavities in rocks. 
Therefore, the essential elements of the images are, generally speaking, mountains and water, those which literally consist of the Chinese and Korean word for landscape, Sansu (San 山 - mountains, $\mathrm{Su}$ 水 - water). Mountains give the impression of strength and durability. A lonely peak, surrounded by a mountain range symbolizes the power of sovereign authority over the subjects. Water is also a symbol of strength. Seemingly weak, submissive, by flowing is gaining strength, passes the entire surface of the earth. Its power washes out even the hardest rock. The water also represents destiny or fate.

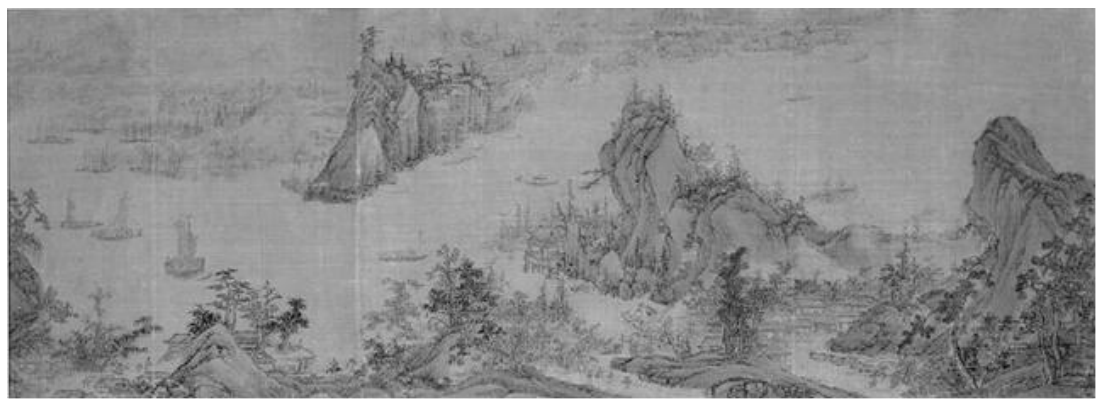

Image 7-1. Yi Inmun, "Eternal mountains and rivers" (1447) Part 1. Watercolours and ink on silk.

A well-known Korean painter who created his works of landscapes in the years 1745-1821 was Yi Inmun, associated with the Chinese North School. His 8.5-meter-long scroll titled "Eternal mountains and rivers" (Gangsanmujindo 汇山無盡圖), is considered by many to be the largest existing traditional Korean landscape, which inspired the title and form of the $12^{\text {th }}$ century Chinese paintings, which during Yi Inmun's lifetime was in the collection of the Emperor of China. 


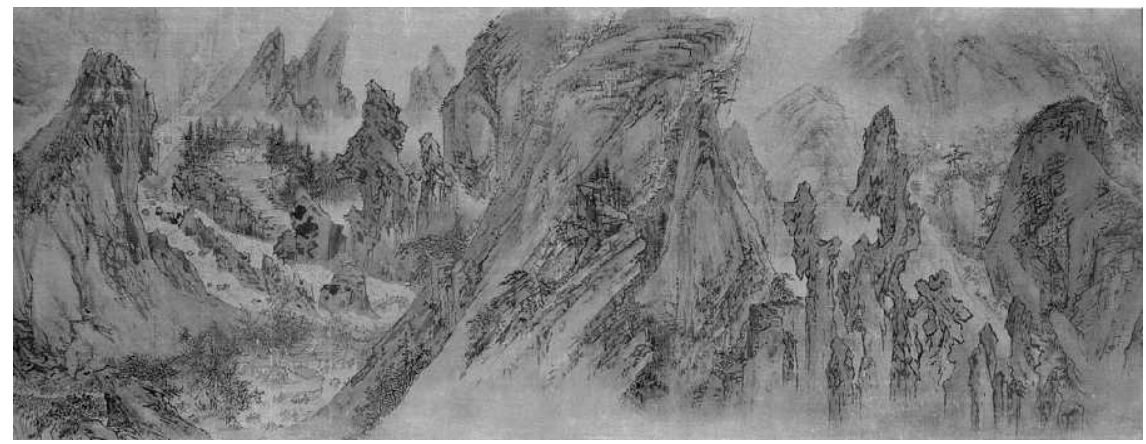

Image 7-2. Yi Inmun, "Eternal mountains and rivers" (1447). Part 2. Watercolours and ink on silk.

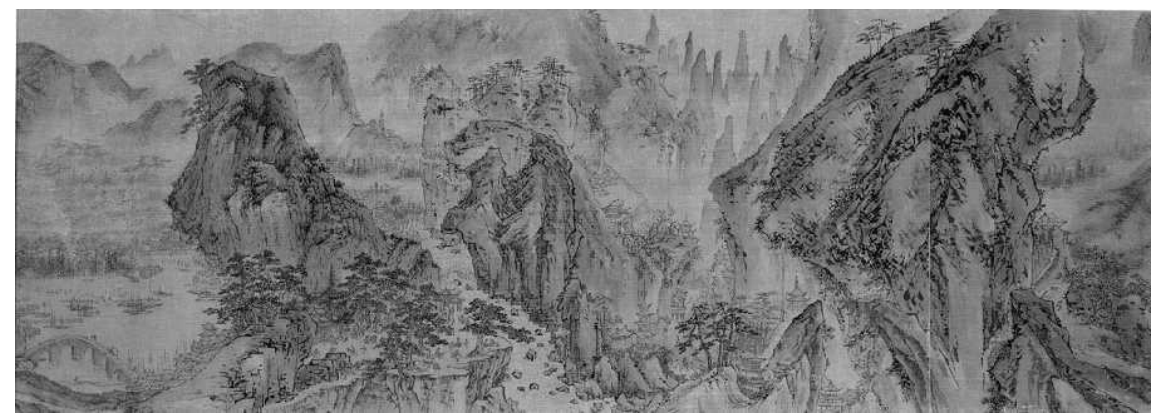

Image 7-3. Yi Inmun, "Eternal mountains and rivers" (1447) Part 3. Watercolours and ink on silk.

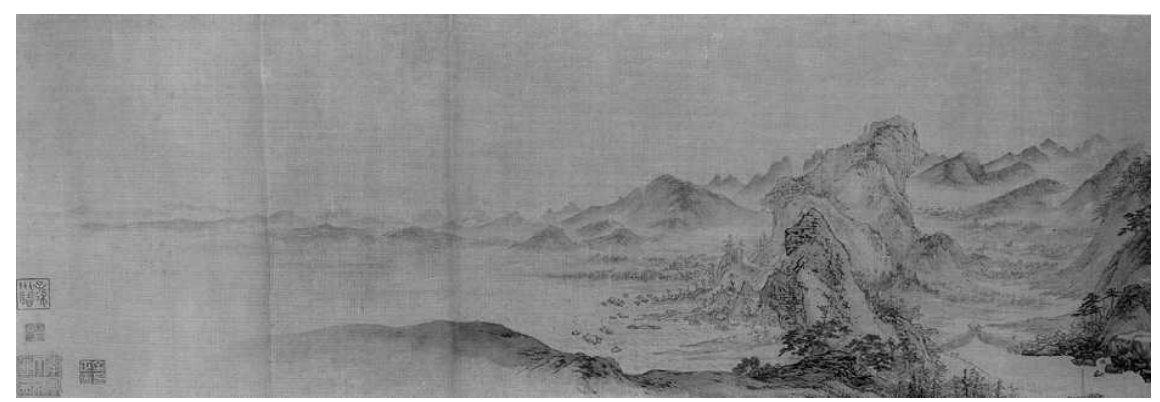

Image 7-4. Yi Inmun, "Eternal mountains and rivers" (1447) Part 4. Watercolours and ink on silk.4. Akwarela i tusz na jedwabiu. 


\section{Koreanization of a landscape: aquisition over imitation}

In the early eighteenth century a new painting trend appeared in the Korean landscape. It is called "Koreanization of the Korean landscape". Korean-style landscapes could not remain entirely Chinese, because there were many differences in the cultural identity and in the forms of nature of these two separate countries. A pioneering role was played by an extraordinary brilliant artist who had the courage to break with the past traditions and develop his own style of landscape painting. It was Jeong Seon (1676-1759). Initially, his early paintings mimicked Chinese patterns, but later he developed his own style, called “realistic landscape (Jingyeongsansu 畺景山水)". Rather than paint idealized scenes according to the Chinese manner, he began to paint what he saw and what he really loved. He used his wellknown painting techniques from China, especially the so-called "small and large axe-cuts (Jeolpajunbeob 浙派㿰法)”.

Jeong Seon's own interpretation of "axe cuts" style captures the image's sharp edges, granite rocks and clumps very accurately, highly typical of the landscape of Korea. Chong Son believed that slavish devotion to detail does not necessarily give the atmosphere of reality or realism. He used iterative long and short strokes of black ink, then added a bit of coloured inks, with which he obtain good results when painting the landscape of "Diamond Mountains" (Geumgangjeondo 金岡全圖). Viewers may well feel the mood of the mountains and towering cliffs and forests. 
Hye Seung LEE: Tradition of Korean Landscape ...

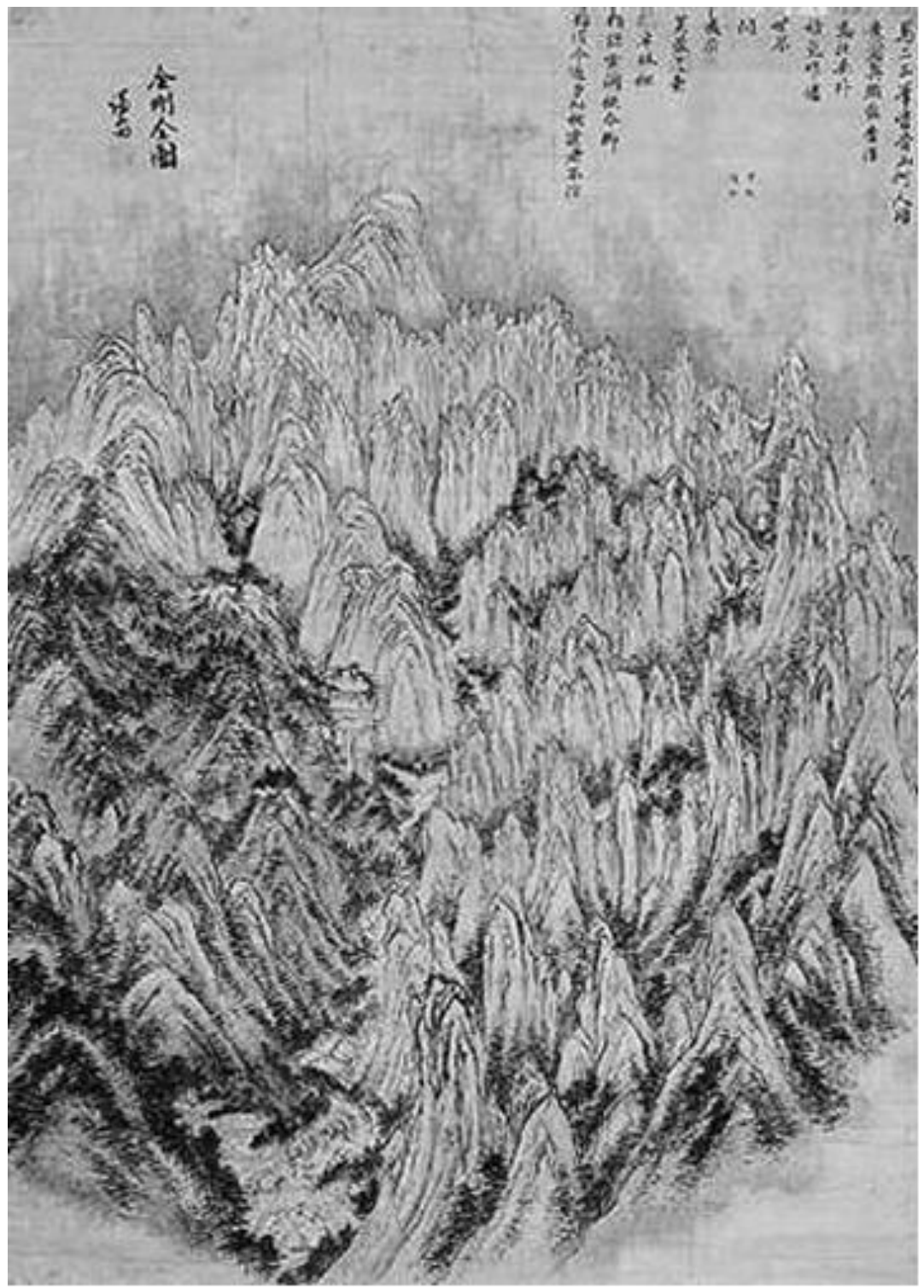

Image 8. Jeong Seon. "Diamond Mountains" (1734) watercolours and ink on paper. 
A more impressionist style, than that of Jeong Seon, was developed by Kang Sehwang (1713-1791), who, using colorful paints, painted a series of "Scenic Spots of Songdo - the old capital of the Goryeo Dynasty" (Songdo gihaengcheob 松都紀行帖). It shows clear outlines of massive rocks with stylized pine trees and vaguely sketched human figures.

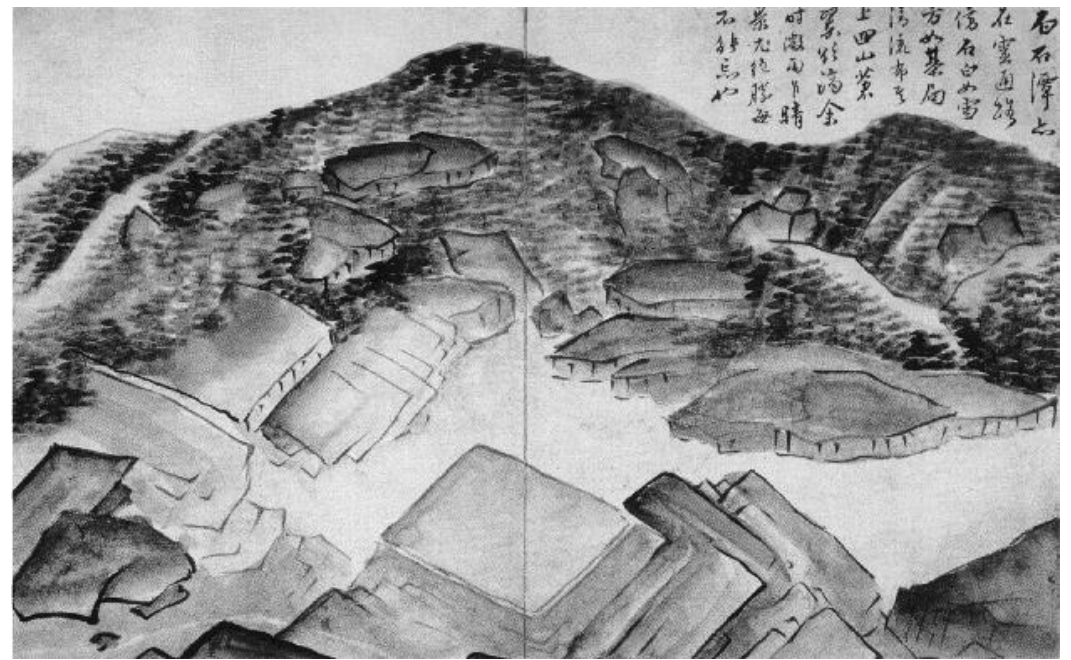

Image 9. Kang Sehwang, a series of Pond with White Rocks. Watercolours and ink on paper.

Artists who did not represent a very high level of painting created their works in a different way, because landscapes belonging to folk art could take more fantastic form. Folk artists, like any other great artists, were particularly fascinated with the unique atmosphere of Geumgang (金剛山) which means Diamond Mountains. This land of countless rocky peaks, which for a long time was associated with the existence of gods and spirits, has been immortalized in legends and art. Monks and hermits could find their shelter in the Diamond Mountains. Painters wanted to present the grandeur of these mountains with all kinds of methods known to them. Sometimes the composition of images show some complex forms of the real view. We often notice an artist's good skills but shapes, colours and situations are imaginary. They are characterized by the spontaneous simplicity. The 
emotions Diamond Mountains evoke, inspire both professional and amateur painters.

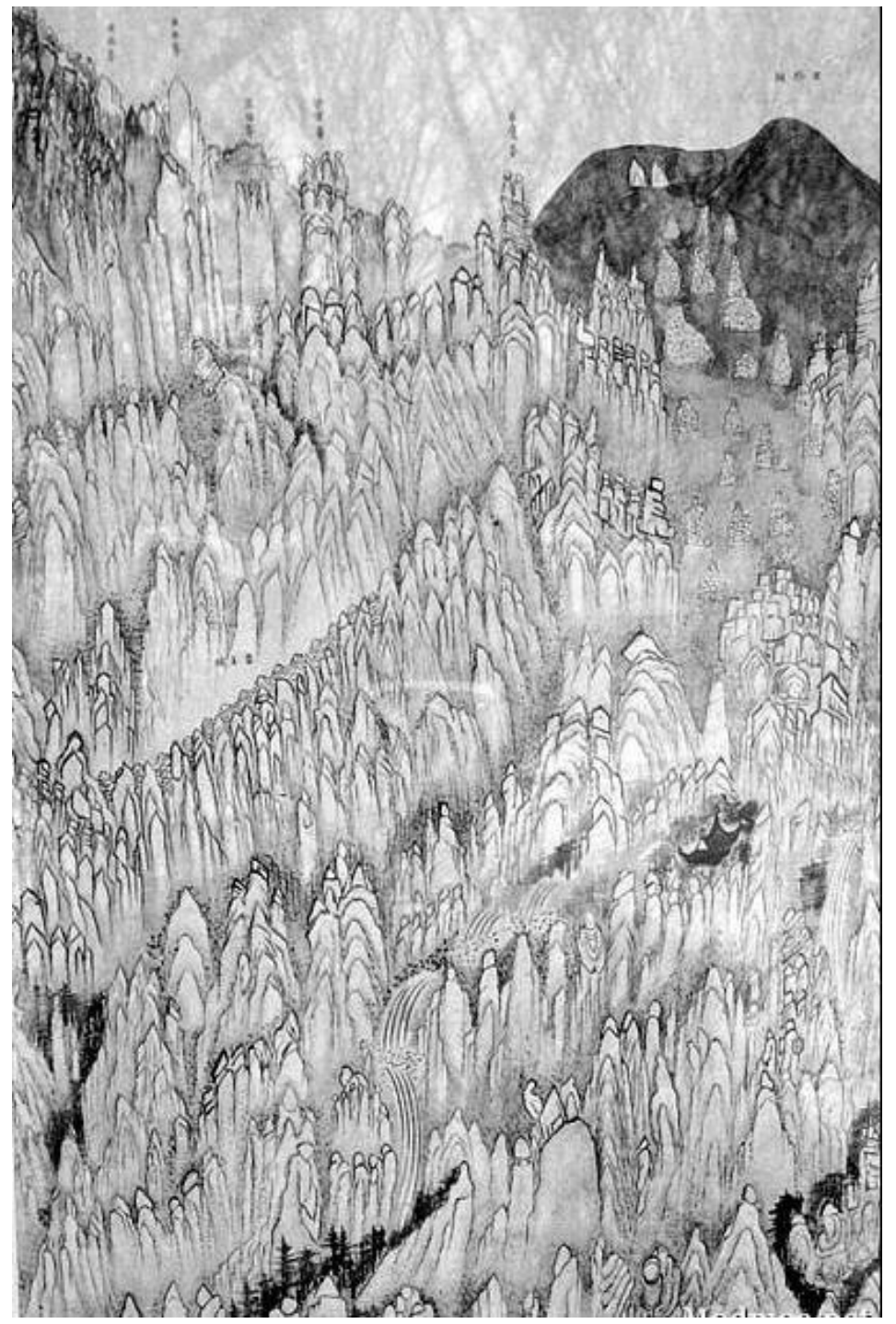

Image 10. Author unknown, The Dimond Mountains (the turn of the $18^{\text {th }} / 19^{\text {th }}$ century) watercolours and ink on paper 
International Journal of Korean Humanities and Social Sciences
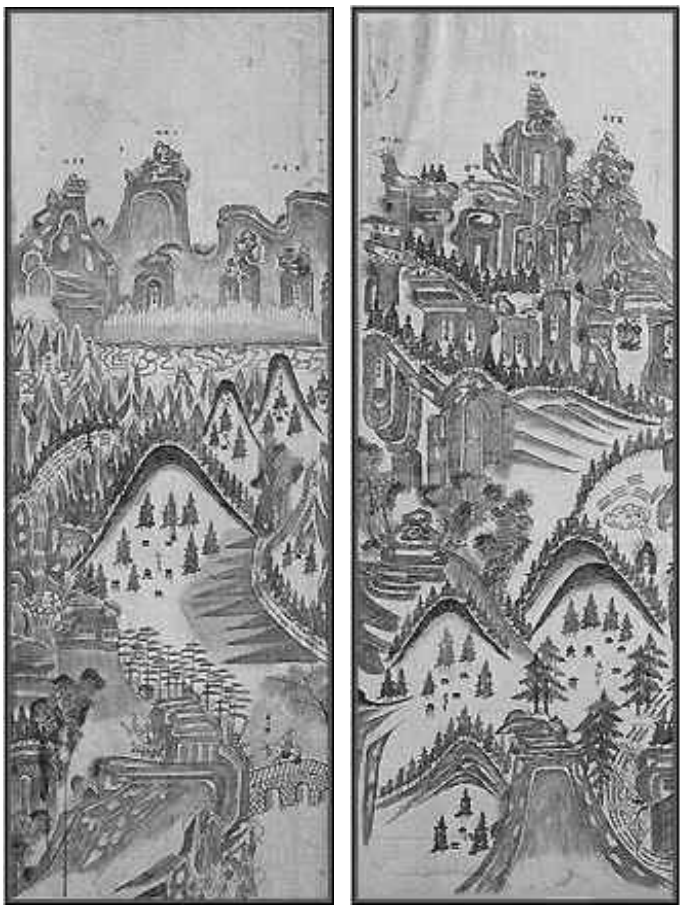


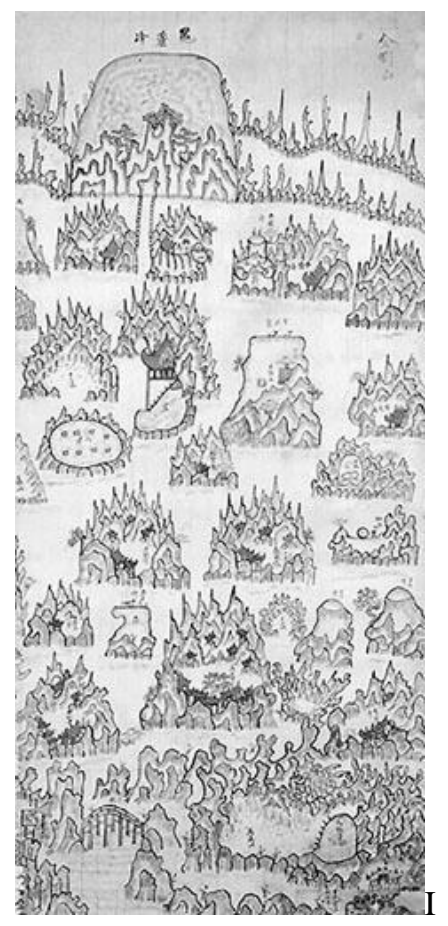

mage 11. Author unknown, folk painting motif of The Dimond Mountains $\left(19^{\text {th }}\right.$ century) watercolors and ink on paper

Artists belonging to the lower classes were not bound by proChinese trends nor created works under their influence. Therefore, in the landscapes of folk painters, there often were fantastic elements. These images have the same elements and format as the other ones, and their vertical formats were a good base to present high cliffs and waterfalls. Here as well there are real or imaginary landscapes. Just like Jeong Seon, folk artists were particularly fascinated by the Geumgang, the Diamond Mountains.

Some of the $20^{\text {th }}$ century painters successfully imitated the style of the West, but the East Asian tradition still had a strong influence on the Korean imagination. An artist whose work shows traces of scholarly tradition of Chinese, local (Korean) originality and his own sense of landscape atmosphere of the early twentieth century was Yi Sangbom 
(1897-1972). Because of the use of fuzzy, muted colours, calligraphic brush use and trade of realism his style was often compared with the work of Chong Son. In his case, however, the use of colours - rotten greens, browns and deep grays - aimed at reflecting the mood of fall and winter - is much more suppressed. The trees in his paintings are often naked and less expansive than in Jeong Seon's landscapes.

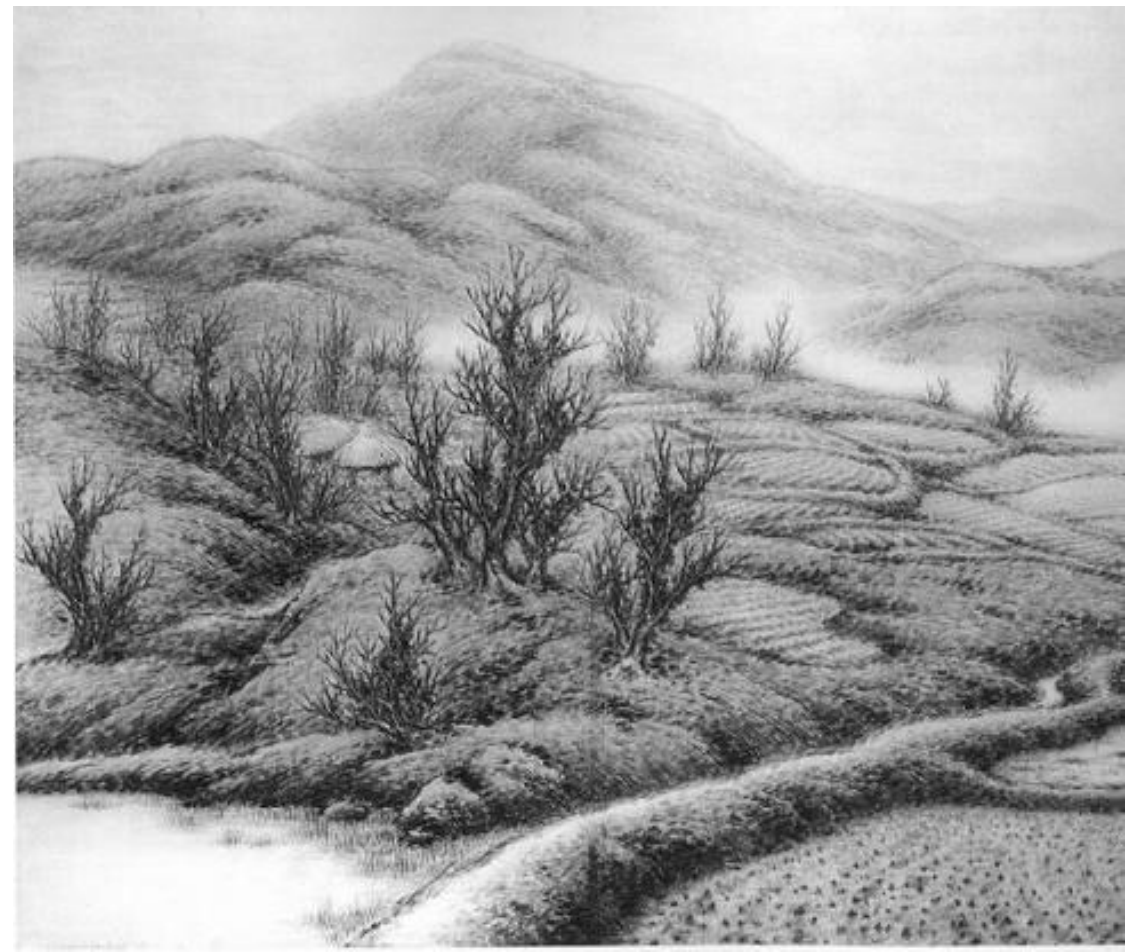

Image 12. Yi Sangbom, "Early Winter" (1926) watercolours and ink on paper

In the contemporary landscape (this only applies to works of landscapes made in the context of continuing the tradition of Korean painting), Korean artists are trying different ways to build their own artistic world. Some lean towards the search to deepen possibilities of ancient painting techniques (eg. Lee Youtae 1916-1999) or strive to combine tradition and folk elements (eg. Kim Gichang 1913-2001). Some attempt to reconstruct Chin'gyongsansu of Chong Son giving this action 
contemporary meaning (e.g. Oh Yonggil 1946-).

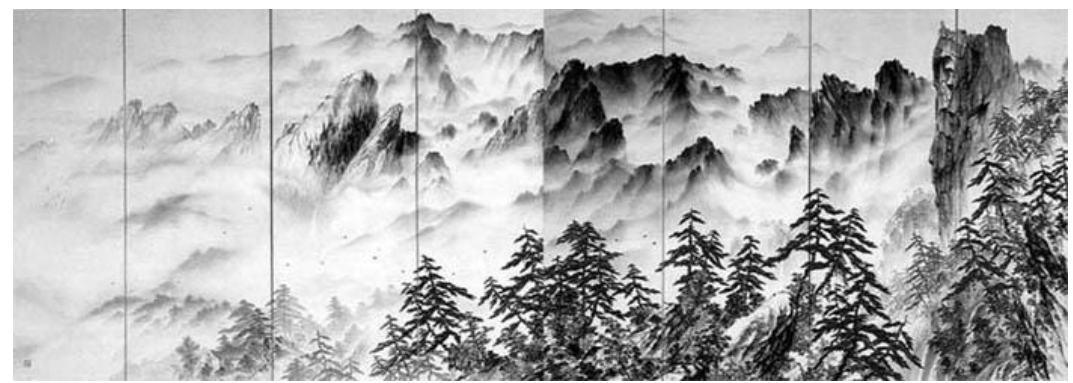

Image 13. Lee Youtae, Sacred Peaks Sollak (1965) watercolours and ink on paper

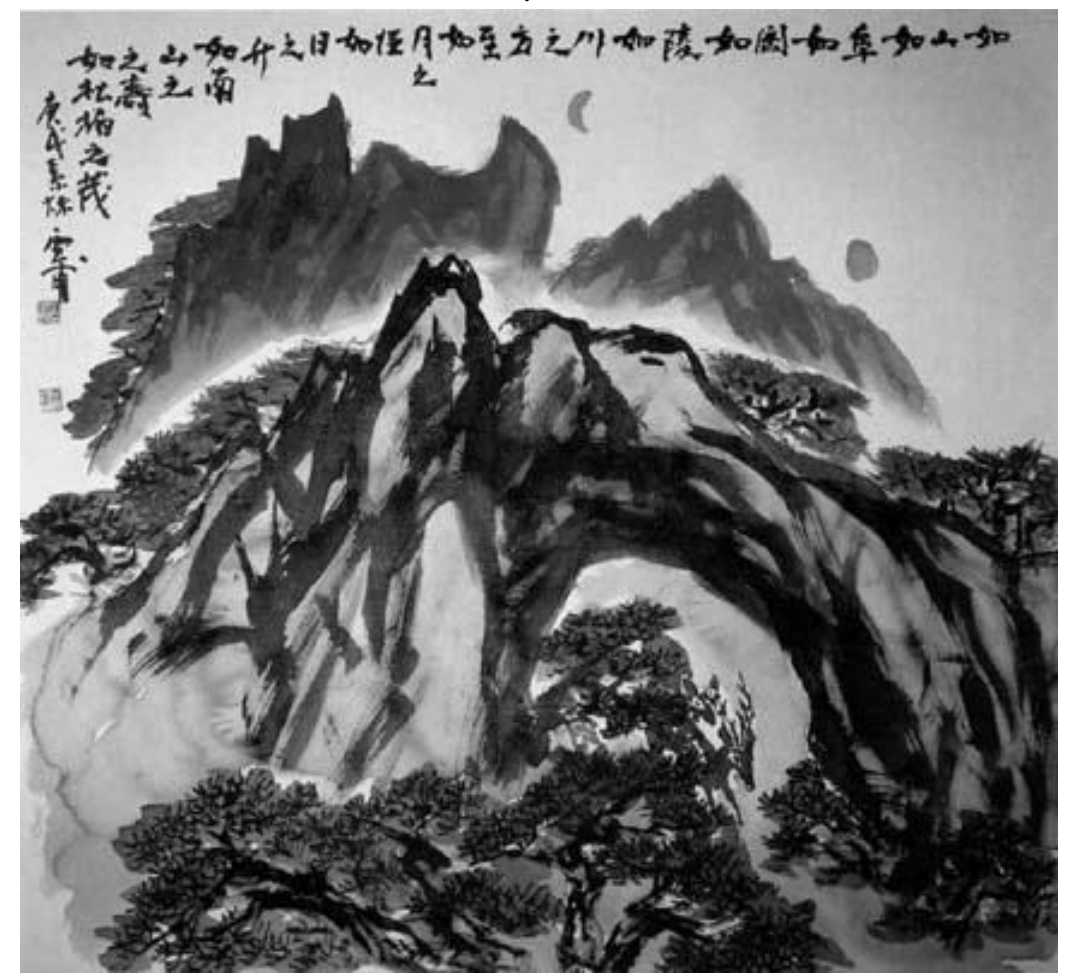

Image 14. Kim Gichang, Landscapes (1970) watercolours and ink on paper 


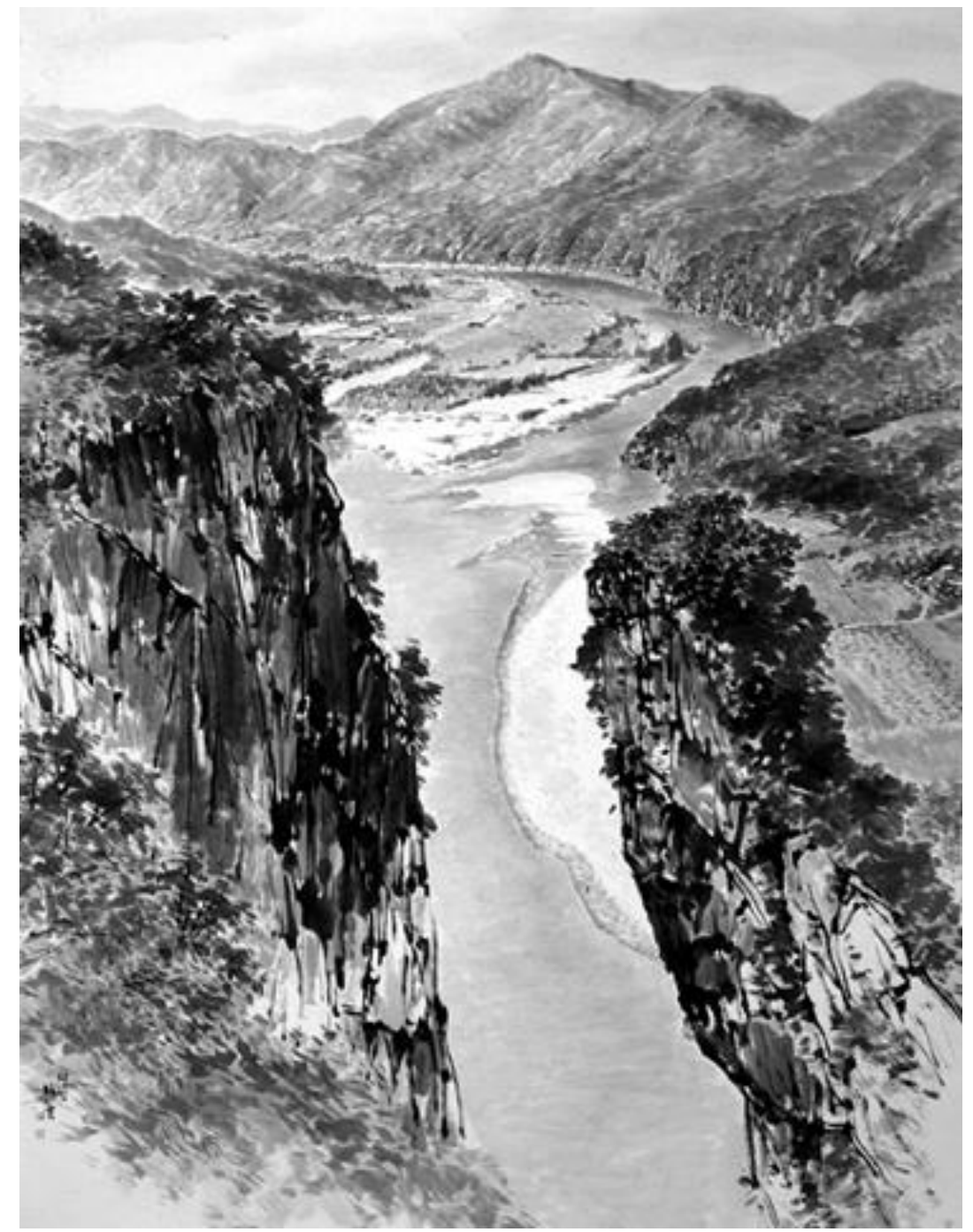

Image 15. Oh Yonggil, River (1987) watercolours and ink on paper 


\section{Conclusion}

Beginning with the Three Kingdoms period, the tradition of Korean landscape painting has developed continously. It is true that there had been a strong prevailing influence of Chinese schools on Korean landscape (mainly in the $10^{\text {th }}-17^{\text {th }}$ centuries), but the spirit of Korean art has not been buried under the advencing foreign techniques. During the Joseon dynasty, Chinese styles which were introduced earlier, were Koreanized. The germination of "true-view" landscape painting - the depiction of actual sites in Korea - began to emerge in documentary painting. Especially, from the 18th century, a cultural golden age lead by a new Korean scholar group "self-awareness and national pride" which declared "we are different from the Chinese". These indigenous characteristics made it possible for various attempts towards the search for one's own artistic world in in the contemporary Korean landscape to emerge.

\section{References}

Ahn, Whijun. 1995. "한국미술 5 천년 조망한다" (Five thousands of Korean art) [in:] 세계일보 (Daily Segye) 2nd of Dec. 1995.

Bush, Susan and Hsiao-Yen Shih, 1985. Early Chinese Texts on Painting. Yenching Institute. Cambridge: Harvard University Press.

Cho, Insoo. 1999. “조선 전기 회화 연구의 길잡이” (Introduction to analyses of the paintings during the earlier period of Joseon dynasty) [in:] 월간미술(Monthly Fine Art). January of 1999.

Kim, Pyongchong. 1989. 중국회화의 조형의식 (Formation Consciousness in Chinese painting). Seoul Univerity Press.

Plante, D. La. 1992. Asian Art. Boston: McGraw-Hill.

Pratt, Keith. 1995. Korean Painting. Oxford University Press.

Song, Soonam. 1995. 한국화의 길 (The way of Korean painting). Seoul: Mijinsa. 
International Journal of Korean Humanities and Social Sciences

Trzeciak, Przemysław. 2002. Idea i tusz. Warszawa: Prószyński i S-ka.

Whitfield, Roderick and Young-Sook Pak, 1986. Korean Art Treasures. Seoul: Yekyong Publishing.

Yu, Junesang. 1995. "Light and color in Korean art". [in:] Koreana.

Vol. 9. Korea Foundation. 